\title{
The Human Capital for Value Creation and Social Impact: The Interpretation of the IR's HC Definition
}

\author{
Maurizio Cisi * (D) and Francesca Alice Centrone \\ Department of Management, University of Torino, 10134 Turin, Italy; francescaalice.centrone@unito.it \\ * Correspondence: Maurizio.cisi@unito.it
}

\begin{abstract}
The paper aimed at assessing and identifying in a comparative way the potentiality and suitability of the Integrated Reporting (IR)'s definition of human capital (HC) within a selection of companies and social cooperatives. Employing in-depth interviews, the qualitative study analyzed the points of view of a selection of human resources managers to firstly check and test the connection between human capital, value creation, and social impact. The contribution of human capital to value creation is not easily recognized, especially by smaller-sized companies. The results suggested that the HC definition of the IR in the for-profit sector seems to be more applicable to the top management than to the whole workforce, while it appears as "fitting" for the managers of social cooperatives because of its explicit focus on ethical values, loyalty, and motivation. This allowed opening possible channels of dialogue between the profit and not-for-profit sectors. The paper proposed practical recommendations to operationalize the IR's HC definition.
\end{abstract}

Keywords: human capital; integrated reporting; value creation; social impact

check for

updates

Citation: Cisi, M.; Centrone, F.A. The Human Capital for Value Creation and Social Impact: The Interpretation of the IR's HC Definition.

Sustainability 2021, 13, 6989.

https://doi.org/10.3390/su13136989

Academic Editor: Andrea Pérez

Received: 3 May 2021

Accepted: 15 June 2021

Published: 22 June 2021

Publisher's Note: MDPI stays neutral with regard to jurisdictional claims in published maps and institutional affiliations.

Copyright: (c) 2021 by the authors. Licensee MDPI, Basel, Switzerland. This article is an open access article distributed under the terms and conditions of the Creative Commons Attribution (CC BY) license (https:/ / creativecommons.org/licenses/by/ $4.0 /)$.

\section{Introduction}

The paper focused on human capital (HC) and value creation dynamics in a selection of Italian conventional firms and social cooperatives. The paper intended to clarify whether the Integrated Reporting (IR) definition of the HC defines a model that could be applicable in order to better manage the value creation process and indirectly influence the potential social impact. To achieve such a goal, researchers interviewed a purposive selection of HR managers from conventional firms and social cooperatives active in the Northwest of Italy.

The IR framework foresees six capitals: financial, manufactured, intellectual, human, social and relationship, and natural. Such capitals are defined as 'stock of value that are increased, decreased, or transformed through the activities and outputs of the organization. This represents one of the main key concepts of the IR and also one of the most criticized' $[1,2]$, mainly because of the difficulties in comprehension and adoption by firms.

One of the main theoretical references followed in the research is the critical accounting approach [3,4]. The critical accounting approach [5] insists on the role of accounting as a catalyst between organizations and companies to make accountability a wider, inclusive, and democratic process focused on their social impact. The paper contributed to the debate on the limits of the conventional accounting/non-financial reporting and accountability models [6,7], especially if applied to the social entrepreneurship sector [8]. This difficulty of adaptation and application of traditional models increases exponentially in measuring, evaluating, and reporting the most intangible elements of organizations, such as HC [9]. The same standard-setters highlight how the $\mathrm{HC}$ is one of the most difficult capitals to be measured and disclosed.

The literature $[10,11]$ has shown that, up to date, the implementation of the IR model is still limited; however, the IR is recognized as a tool for transparency and accountability. Research based on a sample of IR prepared by a sample of 18 European State-owned enterprises between 2013 and 2017 shows an increasing level of disclosure during the observed period [12]. 
Some emerging studies [13,14] are highlighting the potentials and limits [15] of the IR model. This paper can be included in this recent branch of research. In this sense, the purposive sample of Italian companies and social cooperatives can constitute an interesting and challenging field of analysis not sufficiently explored. Additionally, the study intends to practically contribute to the call launched by several authors $[10,16,17]$ to critically stress and explore benefits and constraints related to the IR application and directly contributing to the active debate promoted by the IIRC.

The definition provided by the IIRC states that the HC is related to 'people's competencies, capabilities and experience, and their motivations to innovate, including their:

- $\quad$ alignment with and support for an organization's governance framework, risk management approach, and ethical values $\rightarrow$

- $\quad$ ability to understand, develop and implement an organization's strategy $\rightarrow$

- loyalties and motivations for improving processes, goods and services, including their ability to lead, manage and collaborate'. This definition is closely linked to value creation [18], goes beyond economic performance, and is an extensive and wide concept involving different scales also external to the organizations.

The dynamics between $\mathrm{HC}$ and value creation represent a quite challenging topic to be in-depth studied both from the academics and the practitioners' point of view. The IIRC itself highlighted the difficulties to adequately explore the connections between $\mathrm{HC}$ and value the creation process, in which reporting can play a crucial role for communication and measurement issues. Despite the fact that human capital is increasingly recognized as a relevant driver of corporate competitiveness and sustainability, the limits of financial measurement systems, which cannot fully evaluate intangible resources and are inadequate to deal with the difficulties inherent to managing the development of new emerging assets, are clear [19]. As stated by Beretta et al. [20], intellectual capital disclosure, in fact, is mainly with a backward-looking orientation and with a limited focus on human capital. In order to try to overcome this issue, few studies proposed frameworks for integrating tangible and intangible aspects of HC to comprehensively measure the overall level of human capital, as that by Mubarik et al. [21].

The peculiarity of the present paper is related to its effort to include the HR manager's point of view in the whole analysis, jointly with a more financial-oriented perspective. The same IIRC highlighted that the HR managers were one of the least involved categories in the IR redaction phases. Starting from such challenging aspects, the paper focused on the analysis of the human capital and value creation process within two different types of organizations: conventional firms and social cooperatives. Conventional firms represent a quite well explored scope of analysis for research around IR issues, on the other side, the social cooperatives have been less analyzed. It has been noted that the debate in the social sector around the measurement of social innovation outcomes and impacts mainly reflects the perspective of private social finance that increases the demand for consistent measures to account for the intended social impacts of capital allocation. In response to these demands, a number of organizations have developed methodologies for measuring the success and impact of innovation, attempting to incorporate social and environmental 'bottom lines' [22]. This area of research constitutes an interesting and challenging perspective for a series of reasons. First, the IR appears to be an appropriate framework for combining both qualitative and quantitative elements and is adaptable to structures with entrepreneurial characteristics used to manage multiple capitals and seems to be compatible with multiple objectives and stakeholders' claims as social cooperatives [23,24]. Second, the IR approach appears consistent with nature strongly oriented on mission and commitment typical of some types of social cooperatives focused on disadvantaged people, quite low trained/educated and normally kept outside from the "traditional" job market. Third, the social cooperatives, despite being "quite" formally ignorant of the IR model, are already applying such an approach in practice more than conventional firms with a less holistic vision. 
Starting from the assessment of the HC definition provided by the IIRC, the paper analyzed the links between HC and Intellectual Capital (IC), compared HC and value creation dynamics between conventional and social entrepreneurship, and built some possible bridges and exchange of best practices between them. In particular, the paper addressed the following research questions:

- RQ1: Is the IR's HC definition effective and applicable to both conventional companies (including SMEs) and social cooperatives?

- RQ2: Are the components of the IR's HC definition useful to articulate a clear picture of the value generated by the $\mathrm{HC}$ management of conventional companies (including SMEs) and social cooperatives?

- $\quad$ RQ3: Could the IR be a possible and useful driving force to improve the HC valorization within both conventional companies (including SMEs) and social cooperatives towards the goal of improving social impact?

The paper is organized as follows: first, we introduce the theoretical framework; then we detail the methodology applied in the research; afterward, we explore and discuss the main findings; finally, we expose the final conclusions of the study.

\section{Materials and Methods}

The search for greater accountability, the need for valuable and context-oriented $\mathrm{HC}$ information (not merely quantitative), and the establishment of proper and specific non-financial reporting models constitute some key issues for the whole social economy sector [25,26]. Previous research as that by Tejedo-Romero and Araujo (2021) showed that companies are adapting to new regulations and voluntarily disclosing information on human capital, a trend that signals their commitment to responsible attitudes towards employees and stakeholders [27]. For such reasons, the paper can be inserted within the stakeholder theory framework, which analyses the value creation at the firm level and considers the implications of stakeholders' expectations on the information disclosure process 6/16/21 7:46:00 PMp.m. At the same time, the behavioral decision-making theory, more focused on the individual level and on the firm attributes and stakeholder perceptions, also represents a valuable theoretical framework for the analysis [28] mainly because of its greater attention to the increased IR quality and not only on its implementation process.

While the greater part of the academic literature on IR is mostly focused on the studies of the Intellectual Capital (IC) [16,29-34], looking at the HC as a subcomponent of the IC together with the relational and organizational capitals, only a few works directly addressed $\mathrm{HC}$ in a stand-alone perspective [35,36].

In the last decades, many definitions and interpretations of $\mathrm{HC}$ have been proposed related to the human resources field and around the IC perspective [37-39]. Despite HC and HR (human resources) could be often interchangeably used, HC includes a whole range of factors such as people's knowledge, competencies, experiences, and the full contribution of these to the firm's performance [40]. According to a managerial point of view, $\mathrm{HC}$ is composed by staff know-how, staff formal qualifications or aptitude, union relationships with management, and staff relations [41]. Human capital is captured of 'know-how, education, vocational qualification, work-related knowledge, work-related competencies, entrepreneurial spirit' [20].

At a general level, findings from a cross-country analysis emphasized the role of human capital in enhancing the awareness of and compliance with environmental regulations, thus leading to an improvement in environmental performance [42].

However, the measurement and the impact of the specific human capital is a challenging activity. An example is that of Ortega-Lapiedra et al. [19] that defines a human capital specific index (HCSI) to analyze the influence of firms' human capital in their activities devoted to environmental improvements through innovations to produce new ecological products or to introduce eco-innovative processes based on more sustainable resources and the reduction of waste. The study evidenced empirically that human capital is responsible 
for creating a sustainable competitive advantage in the eco-innovative activities of the business.

Another study has evidenced that both the human capital development and employees' commitment were found to have a partial mediation in the strategic HR management practices and sustainable competitive advantage [43].

These intangible resources are embedded in the context in which they work and can be presented "in action", showing their contribution to value creation [44]. In order to cover the lack of information in regard to the long-term value creation process [45], the IR framework-based disclosures are characterized by a greater variety of items and more emphasis on human capital [46]. Moreover, as stated by Passetti and Cinquini [47], developing an integrated approach to reporting could provide a more complete overview of the companies' characteristics and performance, with the aim to reduce information asymmetry.

Despite its several criticisms and challenges [15,18,48,49], some emerging research has shown that the IR could be a suitable model to be applied also to hybrid and not-for-profit organizations [12].

The general definition given is that hybrid organizations are organizations created in order to address public needs and to produce services that are public in character, at the same time resembling private corporations in the way they are organized and managed [50].

It has been shown that the combination of public and private characteristics in one organization generates ambiguity that manifests itself in the strategic objectives as well as in the structure of the organization. As stated by Cornforth [51], organizational governance is important in helping to manage competing pressures in order not to degenerate into being no different from capitalist forms of businesses. In fact, one of the challenges facing hybrid organizations, such as social enterprises, is how to combine different logics: commercial logic necessary for operating in the market with a 'charitable' logic of pursuing a social mission [52,53].

The ambiguity imposes specific abilities of the management especially, in driving the human capital [50]: research suggested that organizational membership decisions and socialization policies contribute to imbuing members with organizational values and associated working practices so that they may act based on moral reasoning and commitment to organizational goals [52]. It was found that human capital affects social capital [54] and that experience and cognitive ability influence personal relations and complicity. In other terms, the organizational performance also in terms of social impact is strongly influenced by human capital.

One of the starting points of the research lay in the assumption of Gamerschlag and Moeller around the positive cause-effect link between HC reporting and disclosure and the skills [55], motivations, and commitment of the workforce. Producing human "capital" disclosure on the one side allows companies to determine and appreciate the contribution that human resources provide to the overall economy of the company and on the other, to understand how to improve it, through both a qualitative and quantitative assessment done ex ante or ex post as well [56].

The model was based on a relationship between a company's human capital and its financial performance, taking three factors into consideration (see Figure 1):

(1) workforce-related factors (human capital), such as the workforce's capabilities, its motivation, and commitment;

(2) company-internal factors (structural capital) include a company's operational performance, its innovation ability, as well as its corporate culture;

(3) company-external factors (relational capital), parameters outside the company that are relevant to a company's success. 


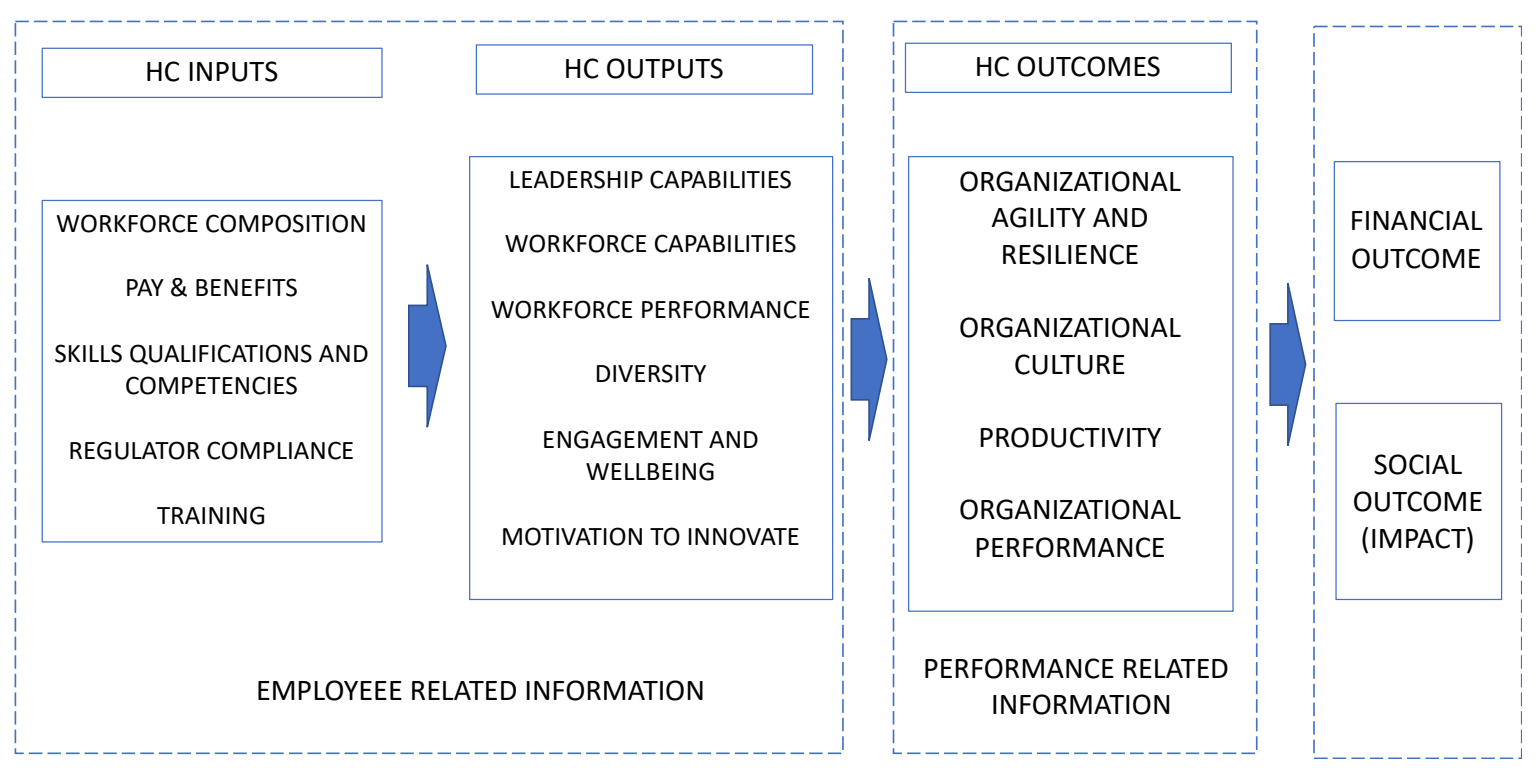

Figure 1. The cause-effect link model.

Our analysis responded to the call launched by Gamerschlag and Moeller to empirically test the veracity of their assumption, focusing in particular on the first factor (the workforce-related or human capital) [55], since it appeared to be the most coherent both with the HC definition of the IR and the core of the paper as well, through semi-structured qualitative interviews addressed to the human resources managers (HR), of ten selected Italian companies and social cooperatives.

The logical process applied in the research was as follows. Starting from the HC definition of the IR, the focus was on three joint levels/ points of views of value creation processes: (1) the value creation for/within the HC concept; (2) the value creation for/within the company/cooperative; (3) the value creation towards the external environment (i.e., the social impact).

In order to explore such value creation processes, the following key issues/drivers were checked: (1) how the HC definition of the IR was adapted to the "work scheme" of the selected organizations; (2) how the single HC definition components effectively contributed to the value creation; (3) whether the social cooperatives expressed a greater level of acceptance/sharing of the HC definition; (4) how such potential greater level of acceptance might imply a better HC management and, thus, a greater internal and external value creation.

The main research statement lay around the hypothesis that whether an organization (mainly a hybrid form as the social cooperative) effectively interpreted and applied all components of the $\mathrm{HC}$ definition of the IR, might consequently improve its performance and management of $\mathrm{HC}$ and, thus, enhance its social impact also outside.

The research approach was qualitative and interventionist [57]. The data collection was based on multiple sources, both primary and secondary data. The primary data were collected from semi-structured interviews addressed to a purposive sample of HR managers coming from companies and social cooperatives active in the Northwest of Italy, while the secondary data (when available) were collected through the content analysis of the NFR (included the companies-integrated reports when available), of their website's sections related to sustainability and CRS issues, and through the reading of other documents (as the social reporting of the cooperatives when available). The combined use of primary data and secondary data made the research design more convincing and consistent [58] allowing to validate the information collected and to identify further insights [59].

The semi-structured interview method (see Appendix A) allowed a certain level of reciprocity between interviewer and participant, enabling to improvise follow-up questions based on the participants' responses [60]. The choice of in-depth and semi-structured 
interviews was in line with the localist perspective in accounting [61] to make it more inclusive and increase its role and social effects. Furthermore, semi-structured interviews allowed understanding 'the way interviewees perceive the social world under study' [57].

The interviews were carried out between February and November 2020. The interviews were addressed to $5 \mathrm{HR}$ managers from 5 conventional firms ( 5 senior) and $4 \mathrm{HRs}$ ( 3 senior and 1 junior) from 3 social cooperatives. The characteristics of the respondents are disclosed in Table 1. Regarding the saturation issues, 9 interviewees have been considered enough by Francis et al. [62] if considered as an initial analysis sample. Additionally, samples in qualitative research tend to be small in order to support the depth of the caseoriented analysis specific to this methodology [63]. Additionally, purposive qualitative samples provide richly-textured information on the investigated phenomenon [64].

All interviews were recorded, transcribed, and analyzed using qualitative content and discourse analysis techniques [65].

The "twin approach" towards sustainability reporting identified by Stubbs et al. [66] shaped the necessity to include the HR perspectives. According to this author, involving both internal and external stakeholders allows achieving an actual Integrated Reporting, with many organizational units active in collecting information, communicating, and reporting as stakeholders contributing to the value creation process [66], improving the whole quality, scope, and usability of the reporting. Accordingly, purposive sampling was used to select key informants (HR managers) with acknowledged expertise by their experiences in leading HC [67].

The 5 HR managers of the conventional firms were selected through the geographical proximity criteria, the very different average number of employees, and different sectors, while the $4 \mathrm{HR}$ of the social cooperatives work for some of the biggest social cooperatives from the Northwest of Italy active in the field-of-work integration of disadvantaged workers.

The comparative lens between conventional firms and social cooperative, despite already applied by other branches of the economy (see, for instance, the works on performance and productivity of Thompson [68] or that on wage differentials of Bailly et al. [69]), represents in our knowledge a quite emerging and challenging approach in the literature on sustainability and integrated reporting and human capital issues [70,71].

The choice of very different types of respondents (see Table 1) has been influenced by the will to achieve a pluralist and broad point of view (in line with the dialogic polylogic accounting approach-see Dillard and Roslender [72]) and to study the perspectives of organizations with different levels of added value in terms of human capital intensity. Additionally, a peculiar aspect regarding the social cooperatives respondents was that both the organizations expressly asked to involve two different persons ( 1 senior and 1 junior from the same department) in the research interviews. This request allowed a different and double point of view on the research topics and also to partially deal with the limited number of involved social cooperatives.

An additional important asset of the selected companies regarded the involvement in the study of 2 companies whose core business was respectively HC management (R3) and IC management (R4). This specialization allowed one to achieve a privileged point of view, mainly in the section of the analysis focused on the connection between HC and IC.

Strictly connected with the willingness to provide a multiple and pluralistic point of view was also the fact that the selected companies provided different types of non-financial reporting. The small and medium conventional firms did not provide any report, 2 social cooperatives provided a social report (which is mandatory for them according to the Italian law), the biggest company of the study was the only which prepared an Integrated Reporting. 
Table 1. Overview of the main respondents' characteristics.

\begin{tabular}{|c|c|c|c|c|c|c|}
\hline $\begin{array}{l}\text { ID } \\
\text { RESPON- } \\
\text { DENT }\end{array}$ & $\begin{array}{l}\text { GENDER } \\
\text { (M/F) }\end{array}$ & $\begin{array}{l}\text { SENIORITY } \\
\text { (Years in the } \\
\text { Company) }\end{array}$ & INDUSTRY/SECTOR & $\begin{array}{l}\text { CONVENTIONAI } \\
\text { FIRM OR } \\
\text { SOCIAL } \\
\text { COOPERATIVE }\end{array}$ & $\begin{array}{c}\text { N. OF } \\
\text { EMPLOYEES }\end{array}$ & $\begin{array}{c}\text { TYPE OF NFR } \\
\text { REPORTING } \\
\text { PROVIDED } \\
\text { (If Any) }\end{array}$ \\
\hline $\mathrm{R} 1$ & M & 8 & Pharmaceutical & $\begin{array}{l}\text { Conventional } \\
\text { firm }\end{array}$ & 560 & n.a. \\
\hline $\mathrm{R} 2$ & $\mathrm{~F}$ & & Taps and fitting & $\begin{array}{l}\text { Conventional } \\
\text { firm }\end{array}$ & 87 & n.a. \\
\hline $\mathrm{R} 3$ & $\mathrm{~F}$ & & Human resources & $\begin{array}{l}\text { Conventional } \\
\text { firm }\end{array}$ & 2293 & IR \\
\hline $\mathrm{R} 4$ & M & & $\begin{array}{l}\text { Intellectual property } \\
\text { consultancy }\end{array}$ & $\begin{array}{l}\text { Conventional } \\
\text { firm }\end{array}$ & 100 & n.a. \\
\hline R5 & M & & Textile & $\begin{array}{l}\text { Conventional } \\
\text { firm }\end{array}$ & 13 & n.a. \\
\hline R6 & $\mathrm{F}$ & 30 & $\begin{array}{l}\text { Welfare, socio-health and } \\
\text { educational services }\end{array}$ & $\begin{array}{c}\text { Social } \\
\text { cooperative }\end{array}$ & 743 & $\begin{array}{l}\text { SOCIAL } \\
\text { REPORT }\end{array}$ \\
\hline R7 & $\mathrm{F}$ & 34 & $\begin{array}{c}\text { Cleaning and } \\
\text { Environmental Services }\end{array}$ & $\begin{array}{c}\text { Social } \\
\text { cooperative }\end{array}$ & 459 & $\begin{array}{l}\text { SOCIAL } \\
\text { REPORT }\end{array}$ \\
\hline $\mathrm{R} 8$ & $\mathrm{~F}$ & 5 & $\begin{array}{c}\text { Cleaning and } \\
\text { Environmental Services }\end{array}$ & $\begin{array}{c}\text { Social } \\
\text { cooperative }\end{array}$ & 459 & $\begin{array}{l}\text { SOCIAL } \\
\text { REPORT }\end{array}$ \\
\hline R9 & M & 22 & $\begin{array}{l}\text { Circular economy/waste } \\
\text { collection and disposal }\end{array}$ & $\begin{array}{c}\text { Social } \\
\text { cooperative }\end{array}$ & 250 & n.a. \\
\hline
\end{tabular}

\section{Results}

The findings from the interviews were divided into the following sections:

1. Knowledge and use of the human capital concept,

2. $\mathrm{HC}$ and social value creation,

3. Value creation through $\mathrm{HC}$ between conventional firms and social cooperatives.

\subsection{Knowledge and Use of the Human Capital Concept}

Concerning the level of sharing and operability with respect to the IR's definition of $\mathrm{HC}$, respondents were asked to respond by using a 5-point Likert scale $(1=$ completely disagree, 5 = completely agree). Almost all respondents answered 3 or 4 . Thus, the level of sharing to the contents of the HC definition of the IIRC appears quite high, even if at the same time such definition has still been criticized for its excessive technicality and the too theoretical and less operational approach. At the same time, the representatives of the social cooperatives showed a double attitude about the efficacy of applying such HC definition to the basis of the cooperative, to the less-skilled workers/working members. On the one hand, the HC definition can be more easily applied to the top management level ('firstly, the motivations to innovate and the ability to understand, develop and implement an organization's strategy', R9), whereas some of the HC definition components ('as the alignment with and support for the organization's governance and the loyalties and motivations towards the final results', R8) could be more efficiently expressed by "simple" working members. Indeed, for them, the support and the loyalty towards the social cooperative itself was very important, representing an actual 'way to take back their

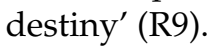

Another point highlighted by some respondents was the possible lack of the HC definition provided by the IR model. Among such identified lacks, one of the most significant ones was the 'self-awareness of people, of workers to be such, to be part of something very specific' (R7).

The empirical study was aimed at verifying whether and how widespread the use of the term HC was within the selected companies since previous research had also high- 
lighted a general preference towards other terms such as people, employees, staff [73]. It could be observed that a slight majority of companies did not use this term in their corporate communication, while most of them usually employ it within their own organization. The company size does not seem to be a determining factor regarding the use of the term HC within companies. One of the most senior respondents, HR of social cooperatives, clearly stated: 'I do not like the use of the word human capital, because (it is) too much connected to the financial capital concept' (R8), while the younger professionals appeared quite open towards the importance of considering the human and financial capital at the same level within the organization.

It was much more interesting to analyze the personal definitions of HC provided by the HR of the companies. Such definitions could be divided into two main categories:

(1) on the one hand, those who see the HC as a physical resource of the company, a "fuel that makes it go", from a perspective mainly oriented to the interest and the point of view of the company;

(2) then, some look primarily at the more "intangible" components of the HC, those related to the skills inherent or developed by employees primarily on a personal and individual level, and not only and solely in the workplace or the formative framework.

This interpretation tends to conceive a closer connection between the company and its staff that can allow the opening of a quite unusual perspective on the delicate dynamics of human capital and the creation of value. On the one hand, the person who leaves the company represents a loss for both parties, from the point of view of the resource, the commitment, and the skills acquired or provided but also about the social and relational capital developed in the company. On the other hand, people (with wrong or right skills and characteristics) placed in the wrong positions can constitute an inefficient investment both in terms of performance and commitment to the company mission as well.

An aspect emerging from the interviews was a sort of division made by some respondents-mainly from the conventional firms-between the 'more skilled and RED employees for which the academic titles count more, and the human capital represented by the less skilled and more operational job positions for which motivation is a greater asset to be considered' (R1). If the technical competencies of people composing the IC are normally clearly recognized by HR, a controversial issue regards the difficulty of the IC "elite" to relate with the HC people entailing quite rare occasions of sharing and cooperation.

The analysis about the level of operationality and possible measurement of the IR's HC definition was performed, streamlining and facilitating the responses through the aggregation of the $\mathrm{HC}$ indicators into different categories as follows:

(1) employee involvement, staff satisfaction rate, motivation, commitment;

(2) corruption, business ethics, respect for human rights;

(3) diversity of staff, gender equality;

(4) experience, training, education;

(5) average age/professional seniority/qualifications, education;

(6) productivity;

(7) turnover, staff loyalty/commitment rate.

Then the respondents were asked to order such indicators according to a Likert scale (1 most significant; 7 less significant).

The HR managers confirmed the difficulty of measuring and evaluating the HC, which is usually applied in a limited way by research companies and, in any case, requires large investments of time and resources generally not accessible by smaller companies.

It emerged that the HRs included multiple indicators that hold together employee involvement/staff satisfaction rate/motivation/commitment in the first place. The parameters of average age/professional seniority/qualifications/education were placed in the second position. On the other hand, in third place, there were some fairly different variables: productivity, staff turnover/retention rate, and corruption/business ethics/respect 
for human rights. Finally, in the "last" position, there was the parameter diversity of the staff/gender equality, a theme that, although it is currently the page for academics and professionals (think also of the growing attention to the issue of diversity and inclusion as an engine for the enhancement of personnel and contribution to the creation of value [74]), from the answers collected it appeared relatively marginal compared to other more "conventional" indicators and macro-themes.

\subsection{HC and Social Value Creation}

In the light of the interviewees' insights, we tried to understand the usefulness of the components of the IR's HC definition to articulate a clear picture of the value generated by the HC management. We Considered, in fact, that the IR's definition of HC is based not only on people's competencies, capabilities, and experience and on motivations to innovate, but it also relies on specific components (such as alignment with and support for an organization's governance framework; risk management approach; ethical values; ability to understand, develop, and implement an organization's strategy; loyalties and motivations for improving processes, goods, and services; ability to lead, manage, and collaborate) that can be directly or indirectly linked with the company's social impact or social value created.

In this second perspective, the HC definition of the IIRC expresses a concept of human capital that is closely linked to the creation of value, and that goes beyond the economic/performance aspects, implying a more extensive concept involving wider areas and scales (as the social, environmental, cultural, etc.) also outside the company $[75,76]$.

Therefore, the research hypothesized that the creation of value (as that described by the IR model) outside the selected organizations might in some way give rise to effects similar to those of the social impact.

The social impact of a company or organization can include social and environmental changes resulting from activities and investments. The impacts on society include issues related to the issues of equality, livelihoods, health, nutrition, poverty, security, and justice [77]. Investments that create social impacts can take various forms and consist of time, skills, material resources, network connections, reputation, and other valuable resources.

Based on the feedback of the HR's responses, we could identify two main dynamics/attitudes.

Firstly, on the one hand, the realities of SMEs explicitly declared that they do not contribute to either of these two effects/phenomena. If this answer could be partly explained by perhaps a limited knowledge and/or mastery of these concepts, on the other hand, an interesting aspect emerged. That is the fact that, although these companies denied contributing in a positive way to the creation of value and/or social impact, in reality, they did so in practice. This contribution could pass primarily from the economic and social benefits that come directly to the families of their employees, to have shown attention to the times of corporate, social, and environmental sustainability since before it became a sort of moral obligation for all business realities, but also to the fact of using a network of expressly local suppliers and sub-suppliers, thus, helping to keep the reference production district active both in terms of employment and relationships of trust.

Secondly, on the other hand, the larger companies (with more than 100 employees) showed that they know these two concepts well and recognize the contribution of their companies without doubts/hesitation. This different attitude could certainly be attributable to greater marketing and communication skills but also certainly to attentive and wellorganized corporate welfare policies that see their contribution in terms of social impact as a mix between the transmission/acquisition of skills, attitudes and positive values, stable employability levels over time, and a combination of different corporate welfare tools. Namely, positive policies that place the 'social impact generated as the starting point and ultimate goal of these business realities, although sometimes it can mean making more efforts and having slower reactions in terms of performance/reaction on the market' (R5). 
A controversial and unexpected point that emerged during the research is that of how we cannot always talk about HC and the "incremental" creation of value, but how sometimes the opposite can happen: that is, a decrease in value 'in terms of loss of social/ethical/skills ... impoverishment of the HC due to the company ... there may be business contexts in which this occurs' (R3). What emerges is that this negative dynamic/vision, which associates a strong moral/social connotation with the concept of value, that is the cause of this impoverishment and should be sought more from the managerial point of view than from that one of the people who are part of it.

\subsection{Value Creation through HC between Conventional Firms and Social Cooperatives}

Partially connected with the topic of the loss of human capital was the specific point of view expressed by the implicit nature of the social cooperatives: 'if you count 1 when you are part of the cooperative when you live it you don't count 0.5 or other, you count 0 ' (R6).

To compare with the for-profit organizations, the interviewed social cooperatives more easily recognized the social impact of their organization. An exhaustive example was offered by R9, who described a quite paradoxical situation where 'people entering in the buildings to collect waste paper were maybe those who before committed crimes inside the same buildings [ ... ]. The same happened with some supermarkets where our former laborers were then employed'. This is to say that quite often, the people/human resources appeared as the first direct witnesses and proof of the social impact generated by the social cooperatives, first, in terms of self-determination, employment, and welfare opportunities. Such employees also expressed a large and shared corporate spirit made of positive and virtuous behaviors to avoid negative effects on the whole organization to which they belong.

Obviously, it is not possible to make a significant comparison between the social impact generated by a social cooperative and a more conventional firm because of their different nature, vision, and mission. However, such findings allow to undermine a series of common key points between these two types of organizations:

- $\quad$ a quite hidden acknowledgment and awareness of the generated social impact;

- $\quad$ a quite general lack of shared and effective quantitative metrics to measure and assess the related social impact;

- a general impression that the external social impact of the organization may, in some cases, appear more easily catchable/caught than the internal social impact.

Some respondents expressed several doubts regarding the efficacy of the social impact concept, which appeared as a quite vague and trend model, rich in quantitative metrics (e.g., increased number of beneficiaries; the scope of the carried-out activities; etc.), not well adapted to be used to assess the actual management of human people and to represent the value creation process inside and outside the organizations.

\section{Discussion}

The first aspect that clearly emerged from the research is the limited mutual knowledge between these two sectors, which, therefore, entails visions strongly conditioned by the backgrounds or personal/social networks of the interviewees. In some cases, the opposite vision between profit and not-for-profit emerges more: 'I can say that we are the polar opposite of the not-for-profit, we belong to an investment fund and we have to soak the return in coffee and milk every morning' (R1).

One of the priority aspects that emerged from the analysis is the vision of a not-forprofit/social enterprise sector more attentive to the ethical dimension of work, in which people are valued more for their level of sharing the mission and values of the organization rather than their skills and performance. About the skill topics, indeed an interesting aspect to be co-opted by the conventional firms should be the skills enhancement process, sometimes "sacrificed" by the social cooperative because 'once you enter there, you adapt yourself, [... ] we don't make treasure of those who are innovative' (R8). Another aspect that could be by the for-profit sector is a more organized and structured process of staff selection. Social cooperatives indeed would tend to privilege the empathic concept than the performance 
or the attitude of people. Conversely, an interesting insight that social cooperatives could bring is the ability and experience related with fragile and marginalized people, those, which normally would be excluded by the conventional labor market.

Closely linked to the theme of the performance was how, among the points in the profit sector that could constitute a virtuous example to export/apply to the non-profit sector, there was a better company organization, respect for deadlines, and deadlines. While, on the one hand, this interpretation could be partially confirmed by the literature on the subject, which describes the difficulties of the not-for-profit sector to approach the issue of the corporate organization more efficiently, on the other, it reflected a vision of the non-profit sector as a sector almost aside; it must not work willy-nilly within the market dynamics of large companies.

Secondly, another relevant aspect of the interviews was the importance of the company size. That is, if at a qualitative level the social impact of the non-profit sector is often seen as greater, at a quantitative level, according to some respondents, larger profit companies would seem to be able to count on a greater reach in terms of social impact. From certain points of view, this vision could find partial confirmation in the past industrial reality of the Italian north-west (see for example how some large historic companies such as FIAT, Olivetti, etc. have in the past largely influenced the human, social, and entire cities through an intense loyalty-building action of its employees, through ad hoc services, and benefits), on the other hand, two possible objections could be outlined. First of all, it was necessary to be careful not to confuse the social impact with the positive effects linked to economies of scale and production districts; furthermore, it could be observed how these large industrial realities have radically changed over time and currently have a territorial presence and an economic (and social) impact, not comparable to the past. The attention that more and more SMEs and social enterprises are showing towards the need to be accountable to the more social and environmental aspects of their activities, despite not representing a legal obligation for them, made us understand how much human capital and value creation, even outside companies, is becoming an increasingly transversal aspect, regardless of company size. Another contact point between the SME and the social cooperative was the existence of less hierarchical relations to compare with the large conventional firms, for instance, 'the HRs know all (employees) by name and surname, ... we are as a big family' (R8).

Despite their different approaches towards human capital and value creation dynamics, both conventional firms and social cooperatives expressed similar points of view about a series of common topics (Figure 2).

In another perspective, the results showed HC and IC as two different but complementary concepts (in line with the IR vision of capitals) and both difficult to be measured and assessed. Strongly connected to the link between HC and IC was also the common topic of the intergenerationality, namely the challenge of balancing innovation and creativity of the younger with the expertise and the usual and "traditional" organizational way of the most senior human resources. In this sense, it may appear significant that both the social cooperatives included in the study decided to involve also some younger colleagues in the interviews, in a general view of skills and duties handover. In Addition, the importance of transferring the knowledge to the new generation is a core value of social enterprises in general.

In this context, the contribution to value creation (whose definition largely varies among the different respondents) and social impact was not easily recognized, especially by the smaller-sized conventional firms. It was quite largely recognized as the mission of the organizations to provide 'thought the job, opportunities of growth, and development of capabilities within a company that partially can be yours' (R6). Conversely, the social cooperatives appeared more conscious of the internal and external value created by its activities because 'the social cooperative must respond to the needs of the local community in terms of fragility and social disease, but also the need for job opportunities' (R6). 


\begin{tabular}{|l|l|c|c|}
\hline OUTCOMES/INSIGHTS & MOTIVATIONS/IMPLICATIONS & $\begin{array}{c}\text { CONVENTIONAL } \\
\text { FIRMS }\end{array}$ & $\begin{array}{c}\text { SOCIAL } \\
\text { COOPERATIVES }\end{array}$ \\
\hline $\begin{array}{l}\text { Difficulty to measure, assess, } \\
\text { and communicate the HC } \\
\text { implications, effects }\end{array}$ & $\mathrm{xx}$ \\
\hline $\begin{array}{l}\text { Limited knowledge of the IR } \\
\text { Framework }\end{array}$ & $\begin{array}{l}\text { Not surprising considering that } \\
\text { most of the selected organisations } \\
\text { are not requested by law to provide } \\
\text { any type ofNFR }\end{array}$ & $\mathrm{xx}$ \\
\hline $\begin{array}{l}\text { Unclarity and unknowledge of } \\
\text { the social impact concept }\end{array}$ & $\begin{array}{l}\text { Due to different reasons i.e } \\
\text { because the organisation is not } \\
\text { completely conscious of its social } \\
\text { impact; because it appears a quite } \\
\text { "fashionable" model not } \\
\text { applicable in the realty, etc. }\end{array}$ & $\mathrm{xxx}$ \\
\hline $\begin{array}{l}\text { Presence of reciprocal bias and } \\
\text { unknowledge/misunderstanding } \\
\text { each other }\end{array}$ & $\begin{array}{l}\text { May impede an effective exchange } \\
\text { of possible best practices around } \\
\text { HC and value creation }\end{array}$ & $\mathrm{xx}$ \\
\hline $\begin{array}{l}\text { General good sharing level } \\
\text { towards the HC definition } \\
\text { provided by the IR model and } \\
\text { quite shared vision on the need } \\
\text { to include also the emotional } \\
\text { component of people/employees } \\
\text { in such definition }\end{array}$ & $\begin{array}{l}\text { x } \\
\text { Positive social effect for all } \\
\text { categories of employees first } \\
\text { the most disadvantaged and the } \\
\text { less skilled) generated by the } \\
\text { actions and by the organisational } \\
\text { model of the selected } \\
\text { organisations }\end{array}$ & $\begin{array}{l}\text { Despite such effect is not well } \\
\text { seported though specific metrics or } \\
\text { criticisms shown by the HRs on a } \\
\text { well-recognised and shared model } \\
\text { (as that of the social impact) }\end{array}$ & $\mathrm{xx}$ \\
\hline $\begin{array}{l}\text { Close link between HC } \\
\text { commitment and value creation } \\
\text { dynamics }\end{array}$ & $\mathrm{xxx}$ \\
\hline
\end{tabular}

Figure 2. Similarities between conventional firms and social cooperatives. Legend: $x=$ not very evident; $x x=$ evident; $x x x=$ very evident.

Regarding the truthfulness of the paper's initial assumptions, which state a similar effect between the HC and value creation process and the social impact, at this stage of the research, partial veracity could be observed. Indeed, for the social cooperatives, this assumption appears more easily confirmed since they highlighted a mission strictly connected to dealing with people's diseases, increasing at the same time their wellness; for the conventional firms, such a link diverged according to the type of sector, organization, etc. In this sense, the most conscious of their social impacts ('we generate value because people live experiences together, exchange, grow together, confront each other', R3) were the companies that, by nature, employ the most qualified people (i.e., as the intellectual capital property consultancy or the human resources management company). Conversely, the most "traditional" and manufactured companies showed more limited awareness and knowledge about the concept and the scope of their social impact ('we cannot speak of a contribution to the creation of value, [here] there is too much gratuitous malice ... everyone looks only at their own reality', R2). A separated discussion should be done with the unique family and SME company (see R5), where the limited number of employees could be translated into an in-depth knowledge and attention both to people's needs, characteristics, and to the local value chain and the environmental and socio-economic milieu as well.

Both the categories (conventional firms and social cooperatives) showed quite diffused HC biases, firstly related to the different levels of commitment and engagement and the 
organizational management and performance. The IR appeared a quite suitable option of NFR also for the social cooperatives, firstly because of its "flexibility". The main challenge relied on how to equilibrate value creation and social effects granting more comprehensive accountability, including both private and social entrepreneurship needs and perspectives. One possible solution could be to overcome the traditional distinction between social and conventional enterprises, focusing mainly on 'good enterprises which means good and accurate management, leaving to the sons a healthy enterprise, valuing its human capital and future generation as well' (R6).

Concerning the initial research questions on the basis of the main findings, we can say that the IR definition of HC can be applicable to both the organizations (RQ1), despite many respondents highlighting its better application to the management level and less to the basis of the workforce, while about RQ2 we can state that the social cooperatives appeared more conscious of the social value creation process generated through their HC management. The same happened in relation to the bigger conventional firms, which presented a more confident attitude, knowledge, and awareness around such topics to compare with the SMEs.

Findings showed that the issue of integrated thinking is still a controversial and quite complex topic to be clearly and effectively explored (in line with Dumay and Day [16]). In some ways, the social cooperatives stressed more the strict connection between financial performance and attention to the environment and the social aspects of their organizations, first, the employee's welfare and commitment. The same happened in relation to their quite strong attention to the relationship with the main stakeholders, suppliers of the territory. Conversely, the bigger conventional firms are more used to operate in an integrated way because of their complex and interrelated structure.

Finally, it could be observed that the IR model (and its definition of HC) has undoubtedly some potentialities for both types of organizations (RQ3), firstly, because of its flexibility 'that in practice seems designed to fit all organizations into the same framework' [78]. Nonetheless, the IR model still presents some limits of application and diffusion.

\section{Conclusions}

The qualitative study analyzed the points of view of a selection of human resources managers to test the connection between human capital, value creation, and social impact.

It seemed that the IR definition of HC is able to define a link between human capital, value creation, and social impact. It is not only based on people's competencies, capabilities, and experience. It is focused on motivation to innovate and on an explicit focus on ethical values, loyalty, and motivation. Even if the contribution of human capital to value creation is not easily recognized, especially by smaller-sized companies, the results suggested that the HC definition of the IR in the for-profit sector seems to be more applicable to the top management than to the whole workforce, while it appears as "fitting" for the managers of social cooperatives.

The research contributed to the theoretical debate on value creation $[79,80]$ and to the more technical discussion on the difficulty of valuing the intangible aspects of organizations [81]. The value creation, its social effects, and its link with HC and IC [82] allow opening possible channels of dialogue between profit and not-for-profit organizations. In this sense, the research responded to the call launched by Girella and Dameri to apply the IR model to the third sector, social enterprises [83]. The research produced practical recommendations to make the IR's HC definition more operational and understandable and has made it possible to outline some steps that can be used to set up a sequential and circular model based on:

(1) recognizing that $\mathrm{HC}$ is an asset for the company (i.e., all respondents speak about $\mathrm{HC}$ but no one looks at it as capital, preferring the use of other concepts such as value, skill, etc.);

(2) evaluating the stock of HC based on personal skills, education-training-attitudes (a phase that normally occurs during the staff selection and hiring); 
(3) acting in order to implement policies aimed at HC stock growth in order to improve the company's performance (in practice, it seems that some larger companies make this operational effort more evident/concrete than others);

(4) assessing the results/impacts of the company actions and policies in terms of increasing the individual sub-components of the HC definition. This is a phase very rarely carried out by organizations, primarily for reasons of excessive complexity and difficulty in measuring intangibles or partly also due to a mismatch between costs and benefits. Further investigations are needed to provide a more complete picture of such critical points.

Considering that most of the analyses have mainly considered the IR preparers' point of view [84], this analysis proposed the inclusion of the non-experts' opinions (like HR managers) around the IR. The positive effects of involving external staff (not normally included in the sustainability and non-financial reporting tasks) to enhance the institutionalization of IR and the integrated thinking in practice has been stressed by scholars (as Guthrie et al. [81]; Dumay et al. [75]), who highlighted the limited research related to the IR practice (instead mostly focused on the normative level) and the lack of the practitioners' contribution to the IR debate. The paper intended to contribute to filling such gaps.

An interesting insight offered by the research was the attempt to propose some categories of KPIs for measuring/evaluating the link between HC and value creation. The orientation of most of the HR managers towards the importance of commitment and the level of involvement of their HC was shown to be consistent with the definition of HC of the IIRC, which revolves around the key concepts of sharing and support of the governance, loyalty, and commitment. The results of the semi-structured interviews showed that the definition of HC provided by the IIRC represents a good level of completeness and recognition by the HC professionals. However, from an improvement perspective, such a definition should also include the most personal and emotional components of people and be integrated to become less abstract and complex.

The main final aim was indeed to make the non-financial reporting process more transparent, shared, and accessible (and consistent with a logic of dialogic polylogic accounting, see De Villiers et al. [18]; Brown and Dillard [82]), and get it out of the usual circuits of experts and large companies accustomed to dealing with the issue. On the other hand, the attention that SMEs are recently showing towards the choice of the IR model justifies the inclusion of SMEs within the research reference target [13,14].

A limitation of the research was represented by the non-inclusion in the respondents of representatives of SMEs, a category of companies which, despite being increasingly attentive to the issue of enhancing the $\mathrm{HC}$ and narrating its sustainability, is less used to dealing with the metrics of non-financial reporting.

In this context, an interesting starting point for future investigations concerns the inclusion of specific parameters on HC health issues within the KPIs proposed for measuring/evaluating the link between value creation and human capital. An innovative contribution, which could enhance the current IR definition of HC, mostly focused on the "traditional" aspects of human capital (i.e., skills, sharing of values, experience, etc.).

The next step of the research could be to analyze how much the management and protection of people during a period of global emergency can make a difference, both to make companies more performing but also more accountable and appreciated by customers, investors, and lenders. In this sense, it seems necessary that the internal debate within the IIRC also considers the need to include a reference to the healthier aspects and the protection of workers' health, along the lines of what has already been done by the 403 (Occupational Health and Safety) standard of the Global Reporting Initiative (GRI).

The research conducted lay the foundations for investigating, in more detail, the role that marginal actors can play in the debate on the degree of accountability and affordability of Integrated Reporting in companies such as SMEs and social enterprises, both in terms of the definition of contents and metrics that are closer to reality and more inclusive of their potential as possible users of this non-financial reporting tool. 
Author Contributions: Conceptualization, M.C. and F.A.C.; methodology, F.A.C.; software, F.A.C.; validation, M.C. and F.A.C.; formal analysis, M.C.; investigation, F.A.C.; resources, M.C. and F.A.C.; data curation, F.A.C.; writing-original draft preparation, M.C. and F.A.C.; writing-review and editing, M.C.; visualization, M.C. and F.A.C.; supervision, M.C.; project administration, M.C.; funding acquisition, M.C. and F.A.C. All authors have read and agreed to the published version of the manuscript.

Funding: This research received no external funding.

Institutional Review Board Statement: Not applicable.

Informed Consent Statement: Not applicable.

Conflicts of Interest: The authors declare no conflict of interest.

\section{Appendix A}

\section{TRACK FOR INTERVIEWS-ENTERPRISES AND SOCIAL COOPERATIVES}

a. BRIEF INTRO WITH OBJECTIVES AND PRACTICAL IMPLICATIONS OF THE RESEARCH: Focus on the non-monetary value of "human capital" in order to reach a common/shared model but also adapted to the needs of social cooperatives to improve personnel management, decrease turnover, enhance the role of conventional enterprises and social cooperatives in the creation of value for society, and social impact through the enhancement of the HC.

b. PRELIMINARY INFO

- Company/cooperative name

- Typology

- Position held

- Years of seniority in the company

- Number of employees

c. HC AND INTEGRATED REPORT

1. Do you use the term "human capital" (HC) in your organization?

- $\quad$ yes (1)

- no (2)

- in part (3)

2. If you don't use it, why?

3. Alternatively, which term do you prefer to use?

4. Based on your experience, could you give us a personal definition of "human capital" (HC)?

5. For your work, have you ever heard of the Global Reporting Initiative (GRI) or Integrated Reporting (IR)?

- $\quad$ yes (1)

- no (2)

- $\quad$ in part (3)

6. The IR defines HC as "People's competencies, capabilities and experience, and their motivations to innovate, including their:

- Alignment with and support for an organization's governance framework, risk management approach, and ethical values

- Ability to understand, develop and implement an organization's strategy

- Loyalties and motivations for improving processes, goods and services, including their ability to lead, manage and collaborate ".

What do you think of this definition? Do you find it suitable for your organization? 
7. Based on this definition of $\mathrm{HC}$, in your opinion what are the best indicators to measure/evaluate the impact of $\mathrm{HC}$ on the creation of value for your organization (in order: 1 = most important, 7 = least important)? employee involvement/staff satisfaction rate/motivation/commitment corruption/business ethics/respect for human rights staff diversity/gender equality average age/seniority/qualifications/education productivity experience/training/education staff turnover/retention rate

8. In your company/cooperative, the social report or another form of a nonfinancial report:

- is required

- you prepare it even if it is not mandatory

- if you do, which standard do you use?

9. In your opinion, why is it (or not) important to prepare a non-financial report?

10. If you prepare it, what is the most difficult aspect to measure/value/tell when you talk about your HC?

- Measure/evaluate

- Valuing/telling

d. HC AND SOCIAL IMPACT

11. If you refer to the "social capital" of your organization, what comes to your mind?

12. How does the human capital of your company/cooperative influence its social impact?

13. How could the connection between HC and the social impact of your company/cooperative be measured?

e. HC BETWEEN NO PROFIT AND PROFIT

14. In your opinion, what are the main differences of $\mathrm{HC}$ between profit and non-profit?

15. Please indicate a positive aspect of the profit sector that should be co-opted for the management and enhancement of HC in the not-for-profit/world of social cooperatives.

16. Indicate a negative aspect of the profit sector in your opinion that should be avoided or in which the not-for-profit can instead set a good example for imitation.

17. In your opinion, is the social impact generated by the not-for-profit sector greater/lesser/equal to that of the profit sector, or it is not possible to answer this?

18. How can the world of research/university help you to improve your work of valorization, measurement, description of the HC?

\section{References}

1. Cheng, M.; Green, W.; Conradie, P.; Konishi, N.; Romi, A. The International Integrated Reporting Framework: Key Issues and Future Research Opportunities. J. Int. Financ. Manag. Account. 2014, 25, 90-119. [CrossRef]

2. Dumay, J.; Dai, T. Integrated thinking as a cultural control? Meditari Account. Res. 2017, 25, 574-604. [CrossRef]

3. Bebbington, J.; Brown, J.; Frame, B.; Thomson, I. Theorizing engagement: The potential of a critical dialogic approach. Account. Audit. Account. J. 2007, 20, 356-381. [CrossRef]

4. Modell, S. Making institutional accounting research critical: Dead end or new beginning? Account. Audit. Account. J. 2015, 28, 773-808. [CrossRef]

5. Gray, R. Taking a Long View on What We Now Know About Social and Environmental Accountability and Reporting. Issues Soc. Environ. Account. 2007, 1, 169. [CrossRef] 
6. Gray, R.; Gray, S. Accountability and human rights: A tentative exploration and a commentary. Crit. Perspect. Account. 2011, 22, 781-789. [CrossRef]

7. Gray, R.; Bebbington, J.; Collison, D. NGOs, civil society and accountability: Making the people accountable to capital. Account. Audit. Account. J. 2006, 19, 319-348. [CrossRef]

8. Andreaus, M.; Costa, E. Toward an Integrated Accountability Model for Nonprofit Organizations. In Advances in Public Interest Accounting; Costa, E., Parker, L.D., Andreaus, M., Eds.; Emerald Group Publishing Limited: Bingley, UK, $2014 ;$ pp. 153-176.

9. Molloy, J.C.; Chadwick, C.; Ployhart, R.E.; Golden, S.J. Making Intangibles “Tangible" in Tests of Resource-Based Theory: A Multidisciplinary Construct Validation Approach. J. Manag. 2011, 37, 1496-1518. [CrossRef]

10. Vitolla, F.; Raimo, N. Adoption of Integrated Reporting: Reasons and Benefits-A Case Study Analysis. Int. J. Bus. Manag. 2018, 13, 244. [CrossRef]

11. Camodeca, R.; Almici, A.; Sagliaschi, U. Strategic information disclosure, integrated reporting and the role of intellectual capital. J. Intellect. Cap. 2019, 20, 125-143. [CrossRef]

12. Manes-Rossi, F.; Nicolò, G.; Tudor, A.T.; Zanellato, G. Drivers of integrated reporting by state-owned enterprises in Europe: A longitudinal analysis. Meditari Account. Res. 2020. [CrossRef]

13. Del Baldo, M. The implementation of integrating reporting in SMEs: Insights from a pioneering experience in Italy. Meditari Account. Res. 2017, 25, 505-532. [CrossRef]

14. Del Baldo, M. Is It Time for Integrated Reporting in Small and Medium-Sized Enterprises? Reflections on an Italian Experience. In Corporate Social Responsibility and Governance; Idowu, S.O., Frederiksen, C.S., Mermod, A.Y., Nielsen, M.E.J., Eds.; CSR, Sustainability, Ethics \& Governance; Springer International Publishing: Cham, Switzerland, 2015; pp. 183-209. [CrossRef]

15. Eccles, R.G.; Krzus, M.P.; Ribot, S. Meaning and Momentum in the Integrated Reporting Movement. J. Appl. Corp. Financ. 2015, 27, 8-17. [CrossRef]

16. Rinaldi, L.; Unerman, J.; de Villiers, C. Evaluating the integrated reporting journey: Insights, gaps and agendas for future research. Account. Audit. Account. J. 2018, 31, 1294-1318. [CrossRef]

17. Paternostro, S. Integrated Reporting and Social Disclosure: True Love or Forced Marriage? A Multidimensional Analysis of a Contested Concept. In Studies in Managerial and Financial Accounting; Songini, L., Pistoni, A., Baret, P., Kunc, M.H., Eds.; Emerald Publishing Limited: Bingley, UK, 2020; pp. 107-146.

18. de Villiers, C.; Hsiao, P.-C.K.; Maroun, W. Developing a conceptual model of influences around integrated reporting, new insights and directions for future research. Meditari Account. Res. 2017, 25, 450-460. [CrossRef]

19. Ortega-Lapiedra, R.; Marco-Fondevila, M.; Scarpellini, S.; Llena-Macarulla, F. Measurement of the Human Capital Applied to the Business Eco-Innovation. Sustainability 2019, 11, 3263. [CrossRef]

20. Beretta, V.; Demartini, C.; Trucco, S. Does environmental, social and governance performance influence intellectual capital disclosure tone in integrated reporting? J. Intellect. Cap. 2019, 20, 100-124. [CrossRef]

21. Mubarik, M.S.; Chandran, V.G.R.; Devadason, E.S. Measuring Human Capital in Small and Medium Manufacturing Enterprises: What Matters? Soc. Indic. Res. 2018, 137, 605-623. [CrossRef]

22. Antadze, N.; Westley, F.R. Impact Metrics for Social Innovation: Barriers or Bridges to Radical Change? J. Soc. Entrep. 2012, 3 , 133-150. [CrossRef]

23. Costa, E.; Ramus, T.; Andreaus, M. Accountability as a Managerial Tool in Non-Profit Organizations: Evidence from Italian CSVs. Volunt. Int. J. Volunt. Nonprofit Organ. 2011, 22, 470-493. [CrossRef]

24. Brown, J.; Dillard, J. Integrated reporting: On the need for broadening out and opening up. Account. Audit. Account. J. 2014, 27, 1120-1156. [CrossRef]

25. Crawford, L.; Morgan, G.G.; Cordery, C.J. Accountability and not-for-profit organisations: Implications for developing international financial reporting standards. Financ. Account. Manag. 2018, 34, 181-205. [CrossRef]

26. Jiao, L. Multifaceted not-for-profit accountability: Its measurement, cultural context, and impact on perceived social performance. Financ. Account. Manag. 2020. [CrossRef]

27. Tejedo-Romero, F.; Araujo, J.F.F.E. The influence of corporate governance characteristics on human capital disclosure: The moderating role of managerial ownership. J. Intellect. Cap. 2021. [CrossRef]

28. Secundo, G.; Elena Perez, S.; Martinaitis, Ž.; Leitner, K.H. An Intellectual Capital framework to measure universities' third mission activities. Technol. Forecast. Soc. Chang. 2017, 123, 229-239. [CrossRef]

29. Dumay, J.; Bernardi, C.; Guthrie, J.; Demartini, P. Integrated reporting: A structured literature review. Account. Forum 2016, 40, 166-185. [CrossRef]

30. Cuozzo, B.; Dumay, J.; Palmaccio, M.; Lombardi, R. Intellectual capital disclosure: A structured literature review. J. Intellect. Cap. 2017, 18, 9-28. [CrossRef]

31. Dumay, J. A critical reflection on the future of intellectual capital: From reporting to disclosure. J. Intellect. Cap. 2016, 17, 168-184. [CrossRef]

32. Zambon, S. Ten years after: The past, the present and the future of scholarly investigation on intangibles and intellectual capital (IC). J. Intellect. Cap. 2016, 17. [CrossRef]

33. Nicolò, G.; Aversano, N.; Sannino, G.; Tartaglia Polcini, P. ICD corporate communication and its determinants: Evidence from Italian listed companies' websites. Meditari Account. Res. 2017. [CrossRef] 
34. Guthrie, J.; Ricceri, F.; Dumay, J. Reflections and projections: A decade of Intellectual Capital Accounting Research. Br. Account. Rev. 2012, 44, 68-82. [CrossRef]

35. Beattie, V.; Smith, S.J. Human capital, value creation and disclosure. J. Hum. Resour. Costing Account. 2010, 14, 262-285. [CrossRef]

36. Sveiby, K.E. The New Organizational Wealth: Managing \& Measuring Knowledge-Based Assets, 1st ed.; Berrett-Koehler Publishers: San Francisco, CA, USA, 1997.

37. Ployhart, R.E.; Nyberg, A.J.; Reilly, G.; Maltarich, M.A. Human Capital Is Dead; Long Live Human Capital Resources! J. Manag. 2014, 40, 371-398. [CrossRef]

38. Abeysekera, I.; Guthrie, J. An empirical investigation of annual reporting trends of intellectual capital in Sri Lanka. Crit. Perspect. Account. 2005, 16, 151-163. [CrossRef]

39. Kim, D.; Go, S. Human Capital and Environmental Sustainability. Sustainability 2020, 12, 4736. [CrossRef]

40. Hamadamin, H.H.; Atan, T. The Impact of Strategic Human Resource Management Practices on Competitive Advantage Sustainability: The Mediation of Human Capital Development and Employee Commitment. Sustainability 2019, $11,5782$. [CrossRef]

41. Bini, L.; Dainelli, F.; Giunta, F. Business model disclosure in the Strategic Report: Entangling intellectual capital in value creation process. J. Intellect. Cap. 2016, 17, 83-102. [CrossRef]

42. Dilling, P.F.A.; Caykoylu, S. Determinants of Companies that Disclose High-Quality Integrated Reports. Sustainability 2019, 11, 3744. [CrossRef]

43. Terblanche, W.; De Villiers, C. The influence of integrated reporting and internationalisation on intellectual capital disclosures. J. Intellect. Cap. 2019, 20, 40-59. [CrossRef]

44. Passetti, E.; Cinquini, L. A Comparative Analysis of Human Capital Disclosure in Annual Reports and Sustainability Reports. In Value Creation, Reporting, and Signaling for Human Capital and Human Assets; Russ, M., Ed.; Palgrave Macmillan US: New York, NY, USA, 2014; pp. 213-241. [CrossRef]

45. Flower, J. The International Integrated Reporting Council: A story of failure. Crit. Perspect. Account. 2015, 27, 1-17. [CrossRef]

46. Dumay, J.; Bernardi, C.; Guthrie, J.; La Torre, M. Barriers to implementing the International Integrated Reporting Framework: A contemporary academic perspective. Meditari Account. Res. 2017, 25, 461-480. [CrossRef]

47. Thomasson, A. Exploring the ambiguity of hybrid organisations: A stakeholder approach. Financ. Account. Manag. 2009, 25, 353-366. [CrossRef]

48. Cornforth, C. Chapter 13: The Governance of Hybrid Organisations. Handbook on Hybrid Organisations; Edward Elgar Publishing: Cheltenham, UK, 2020; pp. 220-236.

49. Ebrahim, A.; Battilana, J.; Mair, J. The governance of social enterprises: Mission drift and accountability challenges in hybrid organizations. Res. Organ. Behav. 2014, 34, 81-100. [CrossRef]

50. Johanson, J.-E.; Vakkuri, J. Governing Hybrid Organisations; Routledge: Abingdon, UK; New York, NY, USA, 2018.

51. Augusto Felício, J.; Couto, E.; Caiado, J. Human capital, social capital and organizational performance. Manag. Decis. 2014, 52, 350-364. [CrossRef]

52. Gamerschlag, R.; Moeller, K. The Positive Effects of Human Capital Reporting. Corp. Reput. Rev. 2011, 14, 145-155. [CrossRef]

53. Zanda, G.; Lacchini, M.; Oricchio, G. La Valutazione del Capitale Umano Nell'impresa: Modelli Qualitativi e Quantitativi di Logica Economico-Aziendale; G. Giappichelli: Torino, Italy, 1993.

54. Qu, S.Q.; Dumay, J. The qualitative research interview. Qual. Res. Account. Manag. 2011, 8, 238-264. [CrossRef]

55. Yin, R.K. Case Study Research: Design and Methods, 3rd ed.; Applied social research methods series; Sage Publications: Thousand Oaks, CA, USA, 2003.

56. Ryan, B.; Scapens, R.W.; Theobald, M. Research Method and Methodology in Finance and Accounting, 2nd ed.; South-Western, Cengage Learning: Andover, UK, 2002.

57. Galletta, A.; Cross, W.E. Mastering the Semi-Structured Interview and Beyond: From Research Design to Analysis and Publication; NYU Press: New York, NY, USA, 2013.

58. Kenno, S.A.; McCracken, S.A.; Salterio, S.E. Financial Reporting Interview-Based Research: A Field Research Primer with an Illustrative Example. Behav. Res. Account. 2017, 29, 77-102. [CrossRef]

59. Francis, J.J.; Johnston, M.; Robertson, C.; Glidewell, L.; Entwistle, V.; Eccles, M.P.; Grimshaw, J.M. What is an adequate sample size? Operationalising data saturation for theory-based interview studies. Psychol. Health 2010, 25, 1229-1245. [CrossRef]

60. Luborsky, M.R.; Rubinstein, R.L. Sampling in Qualitative Research: Rationale, Issues, and Methods. Res. Aging 1995, 17, 89-113. [CrossRef] [PubMed]

61. Marshall, M.N. Sampling for qualitative research. Fam. Pract. 1996, 13, 522-526. [CrossRef] [PubMed]

62. Benevene, P.; Cortini, M. Interaction between structural capital and human capital in Italian NPOs: Leadership, organizational culture and human resource management. J. Intellect. Cap. 2010, 11, 123-139. [CrossRef]

63. Stubbs, W.; Higgins, C. Integrated Reporting and internal mechanisms of change. Account. Audit. Account. J. 2014, 27, 1068-1089. [CrossRef]

64. Bogner, A.; Littig, B.; Menz, W. Introduction: Expert Interviews-An Introduction to a New Methodological Debate. In Interviewing Experts; Bogner, A., Littig, B., Menz, W., Eds.; Palgrave Macmillan UK: London, UK, 2009; pp. 1-13. [CrossRef]

65. Thompson, S. Towards a social theory of the firm: Worker cooperatives reconsidered. J. Coop. Organ. Manag. 2015, 3, 3-13. [CrossRef] 
66. Bailly, F.; Chapelle, K.; Prouteau, L. Wage differentials between conventional firms and non-worker cooperatives: Analysis of evidence from France. Compet. Chang. 2017, 21, 321-341. [CrossRef]

67. Maas, K.; Schaltegger, S.; Crutzen, N. Advancing the integration of corporate sustainability measurement, management and reporting. J. Clean. Prod. 2016, 133, 859-862. [CrossRef]

68. Costa, E.; Parker, L.D.; Andreaus, M. The Rise of Social and Non-Profit Organizations and their Relevance for Social Accounting Studies. In Advances in Public Interest Accounting; Costa, E., Parker, L.D., Andreaus, M., Eds.; Emerald Group Publishing Limited: Bingley, UK, 2014; pp. 3-21.

69. Dillard, J.; Roslender, R. Taking pluralism seriously: Embedded moralities in management accounting and control systems. Crit. Perspect. Account. 2011, 22, 135-147. [CrossRef]

70. Cisi, M.; Alice Centrone, F.; Corazza, L. Does the Integrated Reporting's definition of human capital fit with the HR manager's perspective? Financ. Rep. 2020, 5-32. [CrossRef]

71. Hunt, V.; Prince, S.; Dixon-Fyle, S.; Yee, L. Delivering through Diversity; McKinsey \& Company: Chicago, IL, USA, $2018 ;$ p. 42.

72. Nicholls, A. A General Theory of Social Impact Accounting: Materiality, Uncertainty and Empowerment. J. Soc. Entrep. 2018, 9, 132-153. [CrossRef]

73. Kroeger, A.; Weber, C. Developing a Conceptual Framework for Comparing Social Value Creation. Acad. Manag. Rev. 2014, 39, 513-540. [CrossRef]

74. Epstein, M.J.; Yuthas, K. Measuring and Improving Social Impacts: A Guide for Nonprofits, Companies, and Impact Investors; Greenleaf Publishing: Sheffield, UK, 2014.

75. Dumay, J.; Guthrie, J.; Farneti, F. Gri Sustainability Reporting Guidelines For Public And Third Sector Organizations: A critical review. Public Manag. Rev. 2010, 12, 531-548. [CrossRef]

76. Costa, E.; Pesci, C.; Andreaus, M.; Taufer, E. Empathy, closeness, and distance in non-profit accountability. Account. Audit. Account. J. 2018, 32, 224-254. [CrossRef]

77. Quarter, J.; Richmond, B.J. Accounting for Social Value in Nonprofits and For-Profits. Nonprofit Manag. Leadersh. 2001, 12, 75-85. [CrossRef]

78. Ryan, C.; Mack, J.; Tooley, S.; Irvine, H. Do Not-For-Profits Need Their Own Conceptual Framework?: A NFP Conceptual Framework? Financ. Account. Manag. 2014, 30, 383-402. [CrossRef]

79. Hussinki, H.; Kianto, A.; Vanhala, M.; Ritala, P. Happy Employees Make Happy Customers: The Role of Intellectual Capital in Supporting Sustainable Value Creation in Organizations. In Intellectual Capital Management as a Driver of Sustainability; Matos, F., Vairinhos, V., Selig, P.M., Edvinsson, L., Eds.; Springer International Publishing: Cham, Switzerland, 2019; pp. 101-117. [CrossRef]

80. McNally, M.-A.; Cerbone, D.; Maroun, W. Exploring the challenges of preparing an integrated report. Meditari Account. Res. 2017, 25, 481-504. [CrossRef]

81. Guthrie, J.; Manes-Rossi, F.; Orelli, R.L. Integrated reporting and integrated thinking in Italian public sector organisations. Meditari Account. Res. 2017, 25, 553-573. [CrossRef]

82. Brown, J.; Dillard, J. Critical accounting and communicative action: On the limits of consensual deliberation. Crit. Perspect. Account. 2013, 24, 176-190. [CrossRef]

83. Girella, L.; Dameri, P. Putting Integrated Reporting Where It Was Not: The Case of the Not-for-Profit Sector. Financ. Rep. 2019, 111-140. [CrossRef]

84. Girella, L.; Zambon, S.; Rossi, P. Reporting on sustainable development: A comparison of three Italian small and medium-sized enterprises. Corp. Soc. Responsib. Environ. Manag. 2019, 26, 981-996. [CrossRef] 